\title{
Gender Aspects of Shadow Employment in the North Caucasus Regions
}

\author{
Zaira Abdulaeva ${ }^{1}{ }^{*}$ Shamil Umatov ${ }^{2}$ \\ ${ }^{I}$ Institute of Socio-Economic Research of the Dagestan Federal Research Centre of the Russian Academy of Sciences, \\ Russia \\ ${ }^{2}$ Dagestan State University, Russia \\ *Email: Zaira-76@yandex.ru
}

\begin{abstract}
For many years, the North Caucasus region has been the leader in unemployment and shadow employment among the Russian Federation subjects. In addition to the economic factor, one of the reasons for the labour market tension is the high birth rate and low death rate in the region, creating enormous reserves of potential labour and significantly increasing labour competition. The problem of employment of women, who represent the least socially protected segment of the population in the region, is particularly acute. The study aims to study the factors that influence the characteristics of women's employment in the North Caucasus republics in the informal sector and increase the gender gap in the labour market in the region.

The article examines the problems of shadow employment in the region and analyses its dynamics in the context of the North Caucasus Federal District subjects. The main focus is on the reasons for women's employment in the informal sector, taking into account the region's peculiarities. The author examines the reasons for women's employment from the economic, social and motivational points of view. Among the specific factors affecting the development of women's shadow employment in the NCFD, early marriages, the presence of many children, low self-esteem, and low education level are indicated. It is proved that the results obtained are essential for government agencies and allow optimising social development programs in the regions aimed at reducing the unemployment rate.
\end{abstract}

Keywords: Informal economy, Shadow employment, Women, region, Education, Marriage.

\section{INTRODUCTION}

One of the key factors that negatively affect any state's economic growth is the high shadow economy development level. According to the International Labour Organisation, more than 2 billion people worldwide (almost two-thirds of the workforce) work in the informal sector [1]. In Russia, in 2018 the share of employment in the informal sector amounted to $20.1 \%$ (19.8\% in 2017) of total employment and the size of the shadow economy, as per Rosinformmonitoring data, reached 20.7 trillion rubles, or $20 \%$ of GDP [2,3]. At the same time, for many years, the most problematic region in terms of shadow employment continues to be the North Caucasus Federal District, where $45.4 \%$ of those employed in the informal sector were registered in 2018. The severity of the employment problem in the NCFD is also aggravated by the high degree of gender inequality in the region, which is the only one among the districts in Russia that shows an excess of female unemployment over the male $(13.9 \%$ against $12 \%$ on average for the period from 2010 to 2016) [4].

Although the topic related to the shadow / informal economy is currently trendy in Russia, however, the gender aspect of the problem is still the least studied. Among the main reasons for this situation, according to Z.A. Khotkina, the following can be attributed: first, many Russian authors underestimate the research capabilities of the gender approach, and this scientific direction itself is not yet sufficiently developed. Secondly, most authors do not attach much importance to the social heterogeneity of workers employed in this field. Therefore, shadow business initiators and the 
employees hired and exploited by them are perceived as "shadow workers". Finally, as noted above, in Russia, informal economic activity is still mostly associated with the shadow economy, and researchers focus primarily on criminal activities, women and their problems remain almost "invisible" in the Russian context, although they are the cheaper and more weak labour force, the most attractive for shadow and informal wage markets [5].

At the same time, the gender approach, in our opinion, allows us to see more clearly and draw a line between the shadow and informal components of economic activity and to understand the mechanisms of the informal economy better. For example, the American researcher Martha Chen believes that there is a close relationship between such statuses as being poor, being a woman and working in the informal economy [6]. And Barbara Harris-White successfully expressed the essence of gender differences, by introducing the notions of two types of the informal economy as "the sector politically weak" - employment for owners and micro-business survival and "spheres politically strong" is a large shady business and corruption [7].

\section{MATERIALS AND METHODS OF RESEARCH}

The study used official data of the State Federal Statistics Service, scientific publications of domestic and foreign scientists, research materials of international organisations that reveal the features of gender differences in the labour market. The following research methods were used: the general scientific method of cognition, which provides a systematic approach to solve the set goal, methods of analysis and synthesis, and comparison method.

\section{STUDY RESULTS AND DISCUSSION}

As Eskenderov A.G., Gadzhiev G.G. and others note, in labour-surplus regions, there is always a huge reserve of the potential labour force in the labour market [8, p.1656]. This significantly increases competition in the formal employment sector and forces potential workers to seek employment in the informal sector.

Thus, the share of people employed in the shadow sector of the NCFD increased annually and increased by 7.5 percentage points from $37.9 \%$ in 2010 to $45.4 \%$ in 2018 (table 1). In the context of the North Caucasus Federal District subjects, the level of employment in the shadow sector in 2010-2018, on average, ranged from 29.6\% (Stavropol Territory) to 55.8\% (Chechen Republic). Moreover, except the Karachay-Cherkess Republic, all regions showed an increase in shadow employment at the end of the analysed period, compared to 2010 , which indicates a deterioration in the district's situation. The undisputed leader in shadow employment

Table 1. The level of shadow employment in the subjects of the NCFD in 2010-2018, \%

\begin{tabular}{|l|c|c|c|c|c|c|c|c|c|c|}
\hline \multicolumn{1}{|c|}{ NCFD Subjects } & 2010 & 2011 & 2012 & 2013 & 2014 & 2015 & 2016 & 2017 & 2018 & $\begin{array}{c}\text { Average } \\
\text { for 2010- } \\
2018\end{array}$ \\
\hline $\begin{array}{l}\text { The Republic of } \\
\text { Dagestan }\end{array}$ & 48,4 & 52 & 51 & 56,1 & 57 & 56,5 & 55,7 & 56,0 & 52,0 & 53,9 \\
\hline $\begin{array}{l}\text { The Republic of } \\
\text { Ingushetia }\end{array}$ & 39,5 & 45,6 & 42,7 & 43,7 & 50,9 & 51,0 & 50,1 & 50,3 & 48,7 & 46,9 \\
\hline $\begin{array}{l}\text { The Kabardino-Balkar } \\
\text { Republic }\end{array}$ & 43,1 & 38,5 & 40,1 & 49,2 & 49,7 & 47,0 & 50,4 & 44,5 & 48,2 & 45,6 \\
\hline $\begin{array}{l}\text { The Karachay- } \\
\text { Cherkess Republic }\end{array}$ & 34,4 & 35,7 & 35,4 & 38,9 & 40,2 & 33,9 & 32,4 & 29,3 & 30,8 & 34,6 \\
\hline $\begin{array}{l}\text { The Republic of North } \\
\text { Ossetia-Alania }\end{array}$ & 31,8 & 34,6 & 35,1 & 36,7 & 30,8 & 40,5 & 34,3 & 37,3 & 33,5 & 35,0 \\
\hline $\begin{array}{l}\text { The Chechen } \\
\text { Republic }\end{array}$ & 50,7 & 29,5 & 41,9 & 63 & 63 & 63,0 & 63,3 & 63,9 & 64,1 & 55,8 \\
\hline Stavropol Territory & 26,8 & 27,6 & 29,6 & 27,6 & 29,3 & 30,9 & 29,0 & 30,4 & 35,0 & 29,6 \\
\hline NCFD in general & 37,9 & 37,8 & 39,4 & 44,2 & 45,1 & 45,6 & 44,7 & 45,1 & 45,4 & 42,8 \\
\hline
\end{tabular}


is the Chechen Republic $-64.1 \%$ in 2018 , the second place is the Republic of Dagestan - 52\%, the third is the Republic of Ingushetia $-48.7 \%$. The informal sector of the economy's lowest employment level was observed in the Stavropol Territory, which increased from $26.8 \%$ in 2010 to $29.6 \%$ in 2018 .

For women in the North Caucasus, the problem of official employment is even more acute due to the particular severity of gender differences in the region. Based on the statistics on women's employment in Russia as a whole (figure 1), it can be argued that the level of women's shadow employment in the NCFD may be even higher due to several regional-specific reasons, which will be discussed below.

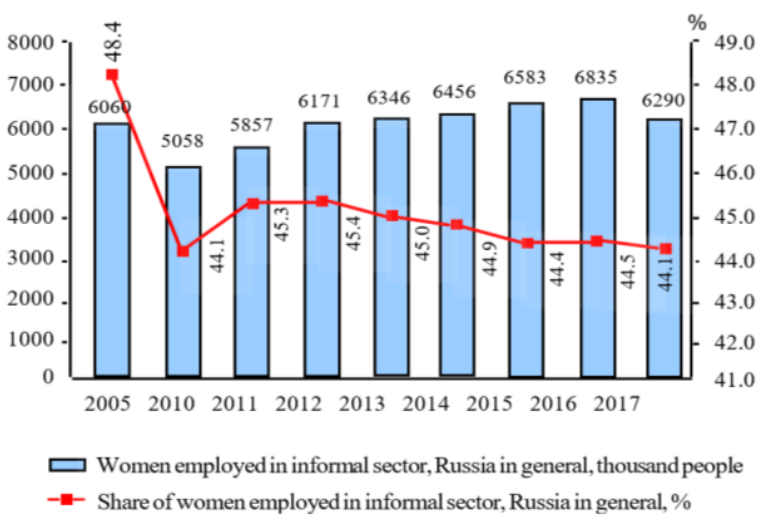

Figure 1 Dynamics of women employed in the informal sector in 2005-2017. Source: calculated by the author according to [2].

Thus, the share of women employed in the informal sector in 2017 in the Russian Federation, in general, amounted to $44.1 \%$ of the total employed population. It should be noted that the share of women's informal employment declined positively in comparison with 2005 when it was at its peak and amounted to $48.4 \%$. Still, the situation in 2017 did not change in comparison with 2010. Moreover, in absolute terms, since 2010, there has been an annual increase in the number of women working in the informal sector (except 2017), which will negatively affect their social protection in the future.

Among the factors that determine the predominant use of female wage labour in the informal economy of the NCFD, the following can be identified:

\section{Economic factors:}

- unfavourable socio-economic norms. In most cases, working in the informal sector is due to the country's high poverty level, forcing women to take up any job to feed their children. Also, informal employment is often identified with a natural and flexible "shock absorber" that allows providing an unlimited amount of selfemployment and income to those who lost their official jobs during the country's crises [9, p.125]. During a crisis, women are much more likely to lose their jobs than men, while the demand for women's work in the formal sector is usually much less. In particular, at the conferences of the International Humanitarian Organisation in Grozny in 2011 and the International Organisation of the North Caucasus in 2009, it was noted that even educated women in Chechnya face the problem of finding a job by their education. Only a tiny number of women hold high positions, and to keep these positions, women must be particularly resourceful. Traditionally, men are the breadwinners. In fact, women are often the breadwinners, usually due to working in the informal employment sector [10, p.11];

- increase in social guarantees from the state [11, p.48]. The North Caucasus Federal district is a region with a high level of social guarantees provided by the state. First of all, this is due to the high birth rate and high unemployment, respectively, the receipt of child benefits and unemployment benefits. In this regard, the fear of losing the guaranteed benefit significantly reduces the desire of women to formalise their employment relations with the employer;

- the low level of wages in the official sector contributes to the active development of informal employment, where the income may be higher than in a public institution [9, p.127];

\section{Social factors:}

- low self-esteem of women may be due to the family, religious, and cultural conditions in which the Caucasus women are located. Thus, brought up in a family with strict patriarchal traditions, a Caucasian woman believes that she must, under religious laws, unconditionally obey her husband, parents, and employer, which makes her an ideal employee in the informal sphere;

- low level of education of women. Parents' unwillingness to provide higher education to their daughters also contributes to informal female employment growth. It should be noted that there is currently a large gap in the level of education between the older and younger generations in the North Caucasus. People in their 50s and 60s who grew up in the Soviet era are generally well educated, and many travelled because of their profession's necessity. Today, young people between the ages of 18 and 25 rarely leave their villages, especially women. Many did not finish high school, and many were left without a job. Very rarely, girls from rural areas and small towns study at the university [10, p.11]. Often, when it is necessary to choose which of the children to give education, preference is given to the son, even despite the worst results in school, compared to the daughter [12]. Moreover, representatives of the International Organisation in the North Caucasus region note the example of women in Chechnya that they do not want to get an education, and men and women treat education differently. For example, of the 60 students of Grozny University who were awarded scholarships, including studying in England and France, there were 
only two women. The problem of women's education in the Caucasus is also aggravated by the fact that if the place of study is located outside of their native place of residence, the woman must be accompanied by her brother or she must live with relatives in the place of study [10, p.11].

At the same time, according to recent studies, higher education has a strong negative impact on the likelihood that a man or woman will enter an informal job. For example, men are 38 percentage points less likely to be employed in the informal sector, and women are 24 percentage points less likely to be employed (figure 2).

- early marriages and having many children. The researchers note that marriage reduces the likelihood that men will engage in informal employment by 9 percentage points and increases the likelihood that women will work in the shadow sector by 13 percentage points. A similar pattern is observed with children: men with children are 25 percentage points less likely to work informally. In comparison, women are 10 percentage points more likely to work informally if they have children (figure 2).

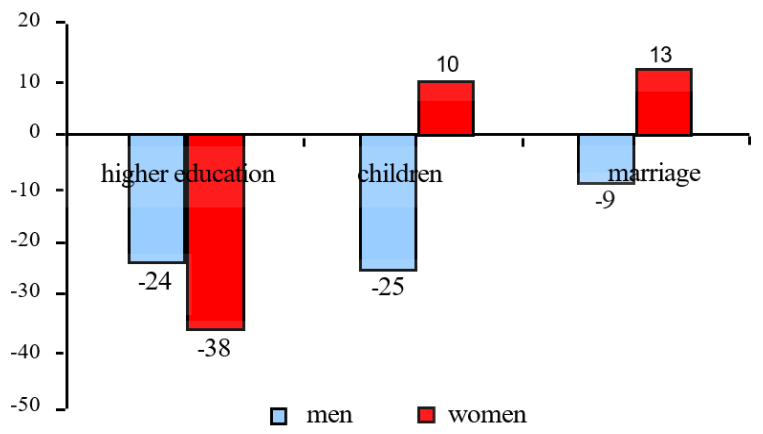

Figure 2 Predictors of informal employment. Source: [14, p. 29].

A certain proportion of girls in the North Caucasus get married before they finish secondary vocational education, which reduces their chances of getting an official job. Thus, in 2016, young people who decided to marry under 18 in the NCFD on average were 19 times less than girls in the same situations. Most women in the North Caucasus Region marry at the age of $18-24$, the share of which in 2015 was $55 \%$, and in 2016- 54.3\% of the total number of married people. Among men, most marriages occur in the age range from 25 to 34 years old - 53.8\% in 2015 and $54.9 \%$ in 2016 [13].

Due to national traditions, the NCFD is the region with the highest birth rate, which makes women uncompetitive and unproductive for the employer for some time, and therefore they prefer to take men to official work. The problem is also aggravated by the lack of available places in kindergartens, which negatively affects women's labour potential in the regions of the NCFD. Thus, as of 2018, 53.3\% of children aged 1-6 are not covered by education in preschool [13]. Also, a certain problem is caused by the opening hours of kindergartens, which do not always coincide with the work schedule. In this regard, one of the parents is looking for a job with a more flexible schedule and preferably near home. The number of vacancies of this kind is limited, which forces one of the parents (mainly mothers) either not to work, or to accept work in the informal sector with the condition of earlier completion of the working day.

\section{Motivational factors:}

- the lack of opportunities for career development and achieving success in life forces women not to try their hand at the official sector, but to immediately switch to informal employment, especially if the work can be done without leaving home (servicing an online store, accounting, writing articles, etc.);

- a free schedule attracts women who have young children who are difficult to identify in preschool or family members who require additional care;

- a low level of confidence in the pension system, which is associated with low pension payments, as well as their equalising nature, which does not fully consider the wages of officially employed employees [11, p.49]. Given that women, for the most part, are employed in low-paid areas (health care, education), the issues of obtaining a decent pension are particularly acute for them.

Summing up, we note that the main specific factors of women's employment in the shadow sector are early marriages and the presence of many children, the availability of social guarantees, low level of education and low self-esteem of Caucasian women.

\section{CONCLUSIONS}

Even though informal employment partially solves the issues of women's employment, it also has several problems related to discrimination in wages and forms of activity (as the ILO notes, in the non-formal sector of the profession, employment guarantees and incomes of women tend to differ from those of men), working conditions and conditions (working overtime and seven days a week, unpaid leave, poor working conditions), violence in the workplace, discrimination in hiring and dismissal (work without an employment contract), etc. Moreover, the gender inequality associated with employment in the informal sector exacerbates poverty, leads to a lack of economic security and self-confidence, reduces opportunities for girls and women, and negatively affects the country's economic growth. In this regard, the State authorities' efforts should strengthen women's economic and legal protection and reduce the gender gap in the labour market. 


\section{REFERENCES}

[1] International Labour Organisation, Care work and care jobs for the future of decent work. Geneva, 2018 [Electronic resource]. Retrieved from: https://www.ilo.org/wcmsp5/groups/public/dgrepo rts/dcomm/publ/documents/publication/wcms_633 $\underline{135 . p d f}$

[2] Labour Force Survey, Federal State Statistics Service. Retrieved from: https://www.gks.ru/compendium/document/13265

[3] Yu. Starostina, Rosstat measured Russia's "invisible" economy, Which industries have gone deeper into the shadows. Retrieved from: https://www.rbc.ru/economics/29/08/2019/5d651e d89a79474a0d725030/

[4] Z.Z. Abdulaeva, The impact of gender stereotypes on the formation of the labour market and employment, Regional problems of economic transformation 8(2018) 129-137.

[5] Z.A. Khotkina, Gender Discrimination in the Informal Economy, 2015. Retrieved from: http://ecsocman.hse.ru/text/16208975/]

[6] Martha Chen, Women and men in the informal economy: a statistical picture. Geneva: Women in informal employment: Globalisation and Organisation (WEGO), 2002. Retrieved from: https://ru.qaz.wiki/wiki/Martha_Chen)

[7] B. Harris-White, "Globalisation and Insecurity: Political, Economic and Physical Challenges", (Wolfson College Lectures, 1999) (London, Palgrave). Retrieved from: https://ru.qaz.wiki/wiki/Barbara_Harriss-White

[8] A.G. Eskenderov, G.G. Gadzhiev, V.V. Kashirin, N.G. Kelbikhanova, Informal employment in a Labour-surplus Region: Approaches to Estimating Scale and Dynamics, Regional Economics: Theory and Practice Vol. 15 Iss. 9 (2017) 1654-1668.

[9] M.I. Glinskaya, Analysis of the spread of informal employment in Russia: causes, Forms and spheres of concentration, Bulletin of the Russian State University of Economics named after G.V. Plekhanov 4(100) (2018) 123-134.

[10] EASO Country of Origin Information Report, Chechnya, Women, Marriage, Divorce and Child Custody, European Asylum Support Office, September 2014, 37 p.

[11] D.R. Akhmadeev, Institutional conditions of informal employment in modern Russia: thesis of $\mathrm{PhD}$ in Economics, Moscow, 2015, 200 p.
[12] V. Bazaeva, Women and Money, Features of Economic Violence in the North Caucasus. Retrieved from: http://womenfd.com/economy/

[13] Regional statistics, Federal State Statistics Service. Retrieved from: https://www.gks.ru/regional_statistics

[14] Women's economic inactivity and engagement in the informal sector in Georgia, UN Women and SDC, Tbilisi, Georgia, 2018, 40 p. 